\title{
USE OF HYPERTEKS TO IMPROVE THE CAPNITIVE ASPECT ABILITY OF SCHOOL BASIC STUDENTS ON A SIMPLE AIRPORT SUPPORT
}

\author{
Ramdhan Witarsa $^{1}$, Irwan Medriana ${ }^{2}$, Dina Medriana ${ }^{3}$ \\ ${ }^{1}$ ElemenaryEducation, STKIP Siliwangi Bandung, Cimahi City, West Java, Indonesia \\ ${ }^{2}$ Cibabat 5 Elementary School, Cimahi City, West java, Indonesia \\ ${ }^{3}$ Cibabat Mandiri 3 Elementary School, CImahi City, West Java, Indonesia \\ 1ramdhansatu@gmail.com, ${ }^{2}$ imedriana@gmail.com, ${ }^{3}$ dmedriana@gmail.com
}

\begin{abstract}
The main issues of this research are how to improve the cognitive aspects of elementary school students on the subject of simple plane through the use of hypertext. The objectives of the research are as follows: (1). Improving cognitive aspects of elementary students through Hypertext; (2). Providing Hypertext learning through a fun and inspiring computer device can inspire elementary students. The methods / approaches used in achieving the following objectives: (a). Collect students and elementary teachers involved in research; (B). Provide an overview of the research activities to be undertaken; $(C)$. Reflecting, discussing the use of hypertext; $(D)$. Collaborate with elementary teachers in the determination of experimental class and control class; (E). Implementation of Hypertext Study; (F). Evaluation of Hypertext Learning. The results showed that there was an increase of cognitive aspect ability of elementary school students through Hiperteks by 33\%; (2). Elementary students are enthusiastic with Hypertext lessons given by teachers; (3). Collaborative occurrence between one student and another student at the time of Hypertext learning is done.
\end{abstract}

Keywords: Learning, Hypertext, Cognitive

\section{INTRODUCTION}

This research is motivated by preliminary research that has been done by the researcher that there is a tendency of elementary school teachers today that oriented more towards learning that minds on and priority of student cognitive aspect. It is highly visible in every draft of the Lesson Plans and at the time the lesson is being conducted. Often teachers give lectures that are memorable and students sit sweetly listen to the teacher's explanation. Students in elementary schools have difficulty in terms of improving their cognitive abilities independently due to teachers in elementary schools who have difficulty in improving the quality of learning, so it greatly affects the ability of cognitive aspects of their students. One effort that can be done by researchers is to try to what extent Hypertext Learning is trying to apply, can improve the cognitive aspects of elementary students.

The application of Hypertext learning that takes into account the unstructured nature of knowledge and makes a learning move through Hypertext is expected to be able to improve the cognitive aspects of elementary students, hence for the purpose that has been disclosed, the need for research "Improving the Capability of Cognitive Aspects of Primary School Students through Hypertext on the principal Simple plane discussion". 


\section{a. Subjects Underlying Research}

The subjects underlying this study are based on general research data previously disclosed and field observation notes in general where the learning process in elementary school is still far from expectations that should be more enable students through independent activities. In science learning in the classroom for example, often less meaningful learning process for students. Students just sit sweet and silent, listen to the teacher's explanation, many teachers stand in front of the class explain the subject matter, and teachers tend to be more active lectures themselves. There is also an indication that teacher pedagogy practices are less appropriate to the topic and do not have an appropriate focus so that experience, both cognitive and psychomotor understandings do not develop optimally.

The $21^{\text {st }}$ Century National Education Paradigm states that the strategy of achieving education in the future one of them is by applying different learning methods in elementary school. This method holds to the principle that each individual is unique and has their own talents, so the learning method must take into account the diversity of "learning style" of each individual. Through independent learning activities through the use of this Hypertext, both students and teachers are expected to further develop its cognitive aspect, whereby when his hands work, the mind works. But much more important is when his hands work and meet obstacles, then develop the mind and trying to find a solution to the obstacles.

Learning models that emphasize these characteristics and diversity need to be developed. Examples of learning models in question include PBL (Problem Based Learning) and the use of Information and Technology (IT). In addition, emphasis should be emphasized on cooperative learning model among individuals to improve their interpersonal and social competence, such as: Cooperative Learning and Collaborative Learning through self-learning activities.

The things that happened that have been expressed before can be understood as kemahluman that really happened in elementary school. Thus there is a need for mentoring and research that can provide examples of various Hypertext lessons so that the students and teachers of the elementary school are more enthusiastic and open to study harder. Through this research, we hope to find meaningful findings on the extent to which Hypertext on improving students' ability in its cognitive aspects. The specific problems we may face are the reluctance of students and elementary teachers to our presence, but through collaborative discussions, we are confident that this will be resolved and this research will provide deep meaning to all of us. 
Hypertext is a learning model that are basically constructivist approach of Piaget and Vygotsky. Constructivism to understand the nature of learning as a human activity to build or create knowledge by trying to give meaning to the appropriate knowledge experience (Nurohman: 2008).

Hypertext is a model that is designed to engage students in exploring information and asked, activities and find, collect data and analyze and draw their own conclusions. In this model, students are given the freedom to construct ideas and findings during the activity so that the students do their own carefree, fun and high motivation so that learning will be more meaningful. Hypertext on learning emphasizes more on the development of reasoning, model building, its association with real-world applications or daily life and can make students have hands-on experience, so as to overcome learning problems such as hard to remember lesson materials (Starrett and Morcos, 2001); (Raviv Daniel, 2004); And (Atles and Ali, 2011).

Characteristics of Hypertext are: independent, mutual support, joyful, passionate learning, integrated learning, using various sources, active students, fun, not boring, sharing with friends, critical and creative students. Hypertext can also provide an in-depth appreciation of what is learned, so that what is obtained by students is not easily forgotten because students get the knowledge directly through their own experience. With the use of Hypertext, students can appreciate the concepts taught by the teacher, the students can prove facts and concepts, and also encourage the students 'curiosity in more depth, so it tends to arouse students' desire to conduct research to gain observation and experience in the scientific process. Through Hypertext, students can also benefit from: increase interest, motivation, strengthen memories, can overcome the problem of learning difficulties, avoid misunderstandings, get feedback from students and connect the concrete and the abstract. (Weinberg, Ithaca and Thomas, 2009) and (Ivers and Whitney, 2009).

In the implementation of Hypertext to be truly effective need to pay attention to several things include: cognitive aspects, affective aspects, and psychomotor aspects. The cognitive domain can be trained by assigning tasks: deepening the theories associated with the task of Hypertext performed, combining the various theories that have been obtained, applying the theories once obtained on the real problem. Psychomotor domains can be trained through: selecting, preparing, and using a set of tools or instruments appropriately and correctly. Affective fields can be trained by: planning independent activities, working with working groups, discipline in working groups, being honest and open and respecting their knowledge. Hypertext makes students become independent, dare to ask questions, explore curiosity and become creative learners. A teacher can and should be able to give students 
experience, at least ten minutes to students where students can feel, hear, see and act on subjects to be taught for the rest of the time. This can create a fun atmosphere, reduce student boredom and learn more effectively.

\section{b. Problem Formulation}

Based on the background that has been disclosed before, this research is directed to answer the problem as follows: "How to Use Hypertext in Improving Ability of Cognitive Aspects of Primary School Students on the subject of Simple Aircraft?". Our problems are detailed through the following research questions:

1. Can Hypertext improve the cognitive aspects of elementary students on a simple plane subject?

2. How big is the improvement of cognitive aspect ability of elementary school students doing the learning through hypertext?

\section{c. Limitations of Research}

Based on the formulation of the problems that have been disclosed, it is necessary to limit the research to make this research more focused. The research limits are given as follows:

1. This study is limited to elementary school science learning.

2. The subjects of the study are grade 4 elementary students.

3. Learning is done through the use of Hypertext.

4. The measured learning outcome is the ability of the cognitive aspects through the test of learning outcomes in the form of a description.

\section{d. Research Purposes}

The purpose of this study as follows:

1. To obtain models and media Hypertext is effective and efficient that can improve the cognitive aspects of elementary students.

2. To obtain a Student Worksheet (LKS) tool for Hypertext learning model developed to guide students for their cognitive abilities to develop optimally.

3. To obtain an appropriate evaluation tool to be able to test the achievement of students' cognitive aspects through Hypertext Learning given.

4. To obtain information about Hypertext Feasibility given in its implementation.

5. To facilitate teachers in delivering learning materials that should be given in the form of Hypertext.

6. To guide elementary students in gaining more knowledge and experience through Hypertext learning. 


\section{e. Output Targets}

The expected output target for this research activity is as follows:

1. Manual manual for guidance on how to develop Hypertext teaching activity in elementary school.

2. The results of research that can be used as material as data and facts when this activity is done, can be a material of further study for the material of final project completion (thesis) / research and can be published nationally through the available educational journals.

3. There is a follow-up research program for the next program development year based on program evaluation, whether conducted by monev team, or SD.

4. As a study material, as for the follow-up research program that can be done as follows: increasing students and teachers who do Hypertext learning.

5. Socialization of collaborative research program of lecturers and students of PGSD STKIP Siliwangi Bandung through $\mathrm{x}$-banner posters that can introduce this program more widely as a result of program implementation.

6. There is an increased understanding of learning at elementary level for both students, as well as teachers.

\section{METHODS}

This research used the experimental method of pretest postes to Hypertext class and Non Hypertext class as control class, where the pretest was done to both classes, then the second class was given different treatment and postes were done to know the final ability of the students after getting treatment, especially in the cognitive aspect.

\section{a. Research Stages}

The steps of research activities that will be carried out as follows:

1. Formulate problems, develop an essay assessment, collect students and elementary teachers who will be the subject of research.

2. Determination of experimental class and control class.

3. Provide an overview of the research activities to be performed.

4. Conducting reflection and discussion about the various activities of Hypertext Learning that will be done.

5. Collaborate with elementary school teachers in the determination of experimental class and control class.

6. Pretest implementation of both classes. 
7. Implementation of Hypertext Learning activities.

8. Evaluation of hypertext learning activities in the form of postes and interviews of students.

\section{b. Research sites}

The research location used is SDN Cibabat 5 and SDN Cibabat Mandiri 3 Kota Cimahi with the number of research subjects 60 elementary school students are divided into two classes.

\section{c. Variables Observed / Measured}

The variables observed or measured in this study are the cognitive aspect ability of elementary school students observed at the time of pretest, implementation, and when postes were conducted.

\section{d. Models Used}

The model used in this research is Hypertext for experimental class, and Non Hypertext for its control class.

\section{e. Data Collection and Analysis Techniques}

Techniques of collecting and analyzing the data carried out following the stages as follows:

a. Provide score to the students' pretest and postes answers.

b. Change the score data of pretest and postes answers into percentages.

c. Determining the average scores obtained by students for each category (group of high, middle, low) students to get the depth of the research results.

d. Determine the percentage of the number of students in each group (high, medium, low).

e. Compare the prestes and postes results of each group.

f. Analyze interview transcripts from each category of students (high, medium, low), to explain other research findings.

g. Conclusion.

\section{RESULTS AND DISCUSSION}

This research activity has been carried out in Cibabat 5 Elementary School and Cibabat Mandiri 3 Cibahi Primary School in February - May 2017 and resulted in several findings that fit the title of "Hypertext Use to Improve the Cognitive Aspects Ability of Primary School Students on Simple Aircraft Subject" . As described in the previous chapter, this study aims to improve the cognitive aspects of elementary school students through hypertext learning. Results and outcomes achieved in this study as follows: 
The research findings obtained in the form of findings of student cognitive research which includes six aspects of cognitive, namely knowledge, understanding, application, analysis, synthesis, and evaluation and interview data. The findings are further analyzed and interpreted.

\section{a. Data on Student Learning Results}

The data obtained to determine student learning outcomes in the form of preliminary and final tests. Initial test is done to determine the students' initial ability before the Hiperteks learning is given and the learning result obtained in the final test is used as a comparison to know the success of the students in following the learning using Hypertext. Initial test result data are presented in the following table:

Table 1

Research Data of Comparative Class (Non Hypertext)

\begin{tabular}{|c|c|c|c|c|c|c|}
\hline \multirow{2}{*}{ No } & \multicolumn{2}{|c|}{ Value } & \multicolumn{2}{|c|}{ percentage } & \multirow{2}{*}{ Gain $(\%)$} & \multirow{2}{*}{ Student Group } \\
\hline & Pretes & Postes & Pretes $(\%)$ & Postes (\%) & & \\
\hline 1 & 0,50 & 2,50 & 5,0 & 25,0 & 20,0 & Low \\
\hline 2 & 0,75 & 2,50 & 7,5 & 25,0 & 17,5 & Low \\
\hline 3 & 1,00 & 2,50 & 10,0 & 25,0 & 15,0 & Low \\
\hline 4 & 1,00 & 5,50 & 10,0 & 55,0 & 45,0 & Low \\
\hline 5 & 1,50 & 7,00 & 15,0 & 70,0 & 55,0 & Low \\
\hline 6 & 1,50 & 4,25 & 15,0 & 42,5 & 27,5 & Low \\
\hline 7 & 1,75 & 3,25 & 17,5 & 32,5 & 15,0 & Low \\
\hline 8 & 1,75 & 5,50 & 17,5 & 55,0 & 37,5 & Low \\
\hline 9 & 1,75 & 6,25 & 17,5 & 62,5 & 45,0 & Low \\
\hline 10 & 2,00 & 5,50 & 20,0 & 55,0 & 35,0 & Medium \\
\hline 11 & 2,00 & 5,50 & 20,0 & 55,0 & 35,0 & Medium \\
\hline 12 & 2,25 & 6,00 & 22,5 & 60,0 & 37,5 & Medium \\
\hline 13 & 2,25 & 8,25 & 22,5 & 82,5 & 60,0 & Medium \\
\hline 14 & 2,50 & 4,00 & 25,0 & 40,0 & 15,0 & Medium \\
\hline 15 & 2,50 & 2,75 & 25,0 & 27,5 & 2,5 & Medium \\
\hline 16 & 2,75 & 3,75 & 27,5 & 37,5 & 10,0 & Medium \\
\hline 17 & 2,75 & 6,50 & 27,5 & 65,0 & 37,5 & Medium \\
\hline 18 & 3,00 & 4,75 & 30,0 & 47,5 & 17,5 & Medium \\
\hline 19 & 4,50 & 1,75 & 45,0 & 17,5 & 27,5 & Medium \\
\hline 20 & 4,75 & 8,25 & 47,5 & 82,5 & 35,0 & Medium \\
\hline 21 & 5,25 & 6,25 & 52,5 & 62,5 & 10,0 & Medium \\
\hline 22 & 5,25 & 8,50 & 52,5 & 85,0 & 32,5 & Medium \\
\hline 23 & 5,50 & 5,25 & 55,0 & 52,5 & $-2,5$ & Medium \\
\hline 24 & 5,75 & 6,00 & 57,5 & 60,0 & 2,5 & Medium \\
\hline 25 & 5,75 & 6,00 & 57,5 & 60,0 & 2,5 & Medium \\
\hline 26 & 5,75 & 7,25 & 57,5 & 72,5 & 15,0 & Medium \\
\hline 27 & 6,00 & 9,50 & 60,0 & 95,0 & 35,0 & Medium \\
\hline
\end{tabular}




\begin{tabular}{lrrrrrl}
\hline \multirow{2}{*}{ No } & \multicolumn{2}{c}{ Value } & \multicolumn{2}{c}{ percentage } & \multirow{2}{*}{ Gain $(\%)$} & \multirow{2}{*}{ Student Group } \\
\cline { 2 - 5 } & Pretes & Postes & Pretes (\%) & Postes (\%) & & \\
\hline 28 & 6,00 & 9,50 & 60,0 & 95,0 & 35,0 & Medium \\
\hline 29 & 6,25 & 5,75 & 62,5 & 57,5 & -5 & Medium \\
\hline 30 & 6,25 & 8,50 & 62,5 & 85,0 & 22,5 & High \\
\hline 31 & 6,25 & 7,00 & 62,5 & 70,0 & 7,5 & High \\
\hline 32 & 6,25 & 7,75 & 62,5 & 77,5 & 15,0 & High \\
\hline 33 & 6,25 & 6,75 & 62,5 & 67,5 & 5,0 & High \\
\hline 34 & 6,50 & 7,25 & 65,0 & 72,5 & 7,5 & High \\
\hline 35 & 7,00 & 8,00 & 50,0 & 80,0 & 11,0 & High \\
\hline Avarage & & 28 & & 39 & & 22 \\
\hline
\end{tabular}

Table 2

Hypertext Class Research Data

\begin{tabular}{lrrrrrl}
\hline \multirow{2}{*}{ No } & \multicolumn{9}{c}{ Value } & \multicolumn{2}{l}{ percentage } & \multirow{2}{*}{ Gain $(\%)$} & \multirow{2}{*}{ Student Group } \\
\cline { 2 - 5 } & Pretes & Postes & Pretes $(\%)$ & Postes $(\%)$ & & \\
\hline 1 & 1,50 & 5,50 & 15,0 & 55,0 & 40,0 & Low \\
\hline 2 & 2,20 & 6,25 & 22,0 & 62,5 & 40,5 & Low \\
\hline 3 & 2,70 & 9,50 & 27,0 & 95,0 & 68,0 & Low \\
\hline 4 & 3,00 & 7,00 & 30,0 & 70,0 & 40,0 & Low \\
\hline 5 & 3,00 & 7,75 & 30,0 & 77,5 & 47,5 & Low \\
\hline 6 & 3,00 & 8,25 & 30,0 & 82,5 & 52,5 & Low \\
\hline 7 & 3,00 & 8,50 & 30,0 & 85,0 & 55,0 & Low \\
\hline 8 & 3,00 & 8,00 & 30,0 & 80,0 & 50,0 & Low \\
\hline 9 & 3,20 & 9,00 & 32,0 & 90,0 & 58,0 & Low \\
\hline 10 & 3,20 & 6,75 & 32,0 & 67,5 & 35,5 & Low \\
\hline 11 & 3,20 & 8,50 & 32,0 & 85,0 & 53,0 & Medium \\
\hline 12 & 3,20 & 9,75 & 32,0 & 97,5 & 65,5 & Medium \\
\hline 13 & 3,50 & 9,00 & 35,0 & 90,0 & 55,0 & Medium \\
\hline 14 & 3,50 & 8,00 & 35,0 & 80,0 & 45,0 & Medium \\
\hline 15 & 3,50 & 8,75 & 35,0 & 87,5 & 52,5 & Medium \\
\hline 16 & 3,70 & 9,75 & 37,0 & 97,5 & 60,5 & Medium \\
\hline 17 & 3,70 & 9,75 & 37,0 & 97,5 & 60,5 & Medium \\
\hline 18 & 4,00 & 9,50 & 40,0 & 95,0 & 55,0 & Medium \\
\hline 19 & 4,00 & 9,00 & 40,0 & 90,0 & 50,0 & Medium \\
\hline 20 & 4,25 & 8,50 & 42,5 & 85,0 & 42,5 & Medium \\
\hline 21 & 4,25 & 8,00 & 42,5 & 80,0 & 37,5 & Medium \\
\hline 22 & 4,50 & 9,00 & 45,0 & 90,0 & 45,0 & Medium \\
\hline 23 & 4,75 & 8,00 & 47,5 & 80,0 & 32,5 & Medium \\
\hline 24 & 4,75 & 8,00 & 47,5 & 80,0 & 32,5 & Medium \\
\hline 25 & 4,75 & 7,50 & 47,5 & 75,0 & 27,5 & Medium \\
\hline 26 & 4,75 & 9,25 & 47,5 & 92,5 & 45,0 & Medium \\
\hline 27 & 5,00 & 8,25 & 50,0 & 82,5 & 32,5 & Medium \\
\hline 28 & 5,00 & 9,00 & 50,0 & 90,0 & 40,0 & Medium \\
\hline 29 & 5,00 & 8,75 & 50,0 & 87,5 & 37,5 & Medium \\
\hline 30 & 5,50 & 9,00 & 55,0 & 90,0 & 35,0 & Medium \\
\hline 31 & 5,50 & 9,25 & 55,0 & 92,5 & 37,5 & High \\
\hline & & & & & &
\end{tabular}

8 | USE OF HYPERTEKS TO IMPROVE THE CAPNITIVE ASPECT ABILITYOF SCHOOL BASIC STUDENTS ON A SIMPLE AIRPORT SUPPORT 


\begin{tabular}{lrrrrrl}
\hline \multirow{2}{*}{ No } & \multicolumn{2}{c}{ Value } & \multicolumn{2}{c}{ percentage } & \multirow{2}{*}{ Gain $(\%)$} & \multirow{2}{*}{ Student Group } \\
\cline { 2 - 4 } & Pretes & Postes & Pretes (\%) & Postes $(\%)$ & & \\
\hline 32 & 6,00 & 9,00 & 60,0 & 90,0 & 30,0 & High \\
\hline 33 & 6,25 & 9,50 & 62,5 & 95,0 & 32,5 & High \\
\hline 34 & 6,25 & 9,25 & 62,5 & 92,5 & 30,0 & High \\
\hline 35 & 6,50 & 9,75 & 75,0 & 97,5 & 42,5 & High \\
\hline Avarage & & & 51,0 & 85,0 & 55,0 & \\
\hline
\end{tabular}

Based on the above table, the average score of the initial tests obtained by the students of the comparison class (non hypertext) is 22 with the highest score of 60 and the lowest 5 , while the Hypertext grade the average score of the initial test 51 with the highest value of 75 and the lowest 10. After tested Statistic, average score of non hypertext grade pre test with hypertext class, the comparison is not much different and the second homogeneous test score score, it shows that the initial ability of both classes before being given treatment is the same.

Based on the above table, the average score of the final test obtained by non hypertext class students is 39 with the highest score of 70 and the lowest is 15, whereas the Hypertext grade the final test score is 80 with the highest score of 98 and the lowest 50. When compared between the scores The average final test of both classes, hypertext grade final score is greater than non hypertext class. The non-hypertext grade gain scores and Hypertext class were obtained from the difference between the initial and final test results.

Based on the above table, the average gain score of non hypertext class is 22 with the highest value of 50 and the lowest -27.5, while the average gain of Hypertext class is 55 with the highest value of 78 and lowest 37 . When compared between the average score of the gain Second class, Hypertext grade average gain score is greater than non hypertext class. This suggests that there is an increase in learning outcomes in Hypertext classes that use Hypertext-based learning as a medium of learning.

\section{b. Statistical Test Results}

Testing of this statistic is done to know the difference of learning result between class which given by using Hiperteks learning with class which given non hypertext learning as class of comparison. Test results for final score as follows:

Table 3

Analysis of Learning Outcomes of Non Hypertext Class and Lower Class Student Hypertension

\begin{tabular}{lrr}
\hline \multirow{2}{*}{ No. } & \multicolumn{2}{c}{ \%Gain } \\
\cline { 2 - 4 } & NH Class & \multicolumn{2}{c}{ Hypertension Class } \\
\hline 1 & 20 & 40,0 \\
\hline 2 & 17 & 40,5 \\
\hline 3 & 15 & 68,0 \\
\hline
\end{tabular}




\begin{tabular}{lrr}
\hline \multirow{2}{*}{ No. } & \multicolumn{2}{c}{ \%Gain } \\
\cline { 2 - 3 } & NH Class & \multicolumn{2}{c}{ Hypertension Class } \\
\hline 4 & 45 & 40,0 \\
\hline 5 & 55 & 47,5 \\
\hline 6 & 27 & 52,5 \\
\hline 7 & 15 & 55,0 \\
\hline 8 & 37 & 50,0 \\
\hline 9 & 45 & 58,0 \\
\hline 10 & 35 & 35,5 \\
\hline Avarage & 31 & 48,0 \\
\hline
\end{tabular}

There is a significant difference in learning outcomes between low-grade students in the Non Hypertext class $(\mathrm{NH})$ with the Hypertext class. Hypertext Learning can increase the percentage of low student learning outcomes from $31 \%$ to $48 \%$.

Table 4

\section{Analysis of Learning Outcomes NH Class and Hypertension Class of Medium Group Students}

\begin{tabular}{lrr}
\hline \multirow{2}{*}{ No. } & \multicolumn{2}{c}{ \% Gain } \\
\cline { 2 - 3 } 1 & NH Class & Hypertension Class \\
\hline 2 & 35,0 & 53,0 \\
\hline 3 & 37,0 & 65,5 \\
\hline 4 & 60,0 & 55,0 \\
\hline 5 & 15,0 & 45,0 \\
\hline 6 & 2,5 & 52,5 \\
\hline 7 & 10,0 & 60,5 \\
\hline 8 & 37,5 & 60,5 \\
\hline 9 & 17,5 & 55,0 \\
\hline 10 & $-27,5$ & 50,0 \\
\hline 11 & 35,0 & 42,5 \\
\hline 12 & 10,0 & 37,5 \\
\hline 13 & 32,5 & 45,0 \\
\hline 14 & $-2,5$ & 32,5 \\
\hline 15 & 2,5 & 32,5 \\
\hline 16 & 2,5 & 27,5 \\
\hline 17 & 15,0 & 45,0 \\
\hline 18 & 35,0 & 32,5 \\
\hline 19 & 35,0 & 40,0 \\
\hline 20 & -5 & 37,0 \\
\hline Avarage & 22,0 & 35,0 \\
\hline & 18,0 & 45,0 \\
\hline
\end{tabular}

There was a significant difference in learning outcomes between students in the $\mathrm{NH}$ group and the Hypertext class. Hypertext Learning can increase the percentage of students' learning outcomes in moderate groups from $18 \%$ to $45 \%$. 
Table 4

Analysis of NH Class Outcomes and Hypertext Class High Class Students

\begin{tabular}{lrr}
\hline \multirow{2}{*}{ No. } & \multicolumn{2}{c}{$\%$ Gain } \\
\cline { 2 - 3 } & NH Class & \multicolumn{1}{c}{ Hypertext Class } \\
\hline 1 & 7,5 & 37,5 \\
\hline 2 & 15,0 & 30,0 \\
\hline 3 & 5,0 & 32,5 \\
\hline 4 & 7,5 & 30,0 \\
\hline 5 & 10,0 & 32,0 \\
\hline Avarage & 9,0 & 32,0 \\
\hline
\end{tabular}

There is a significant difference in learning outcomes between high grade students in $\mathrm{NH}$ classes with Hypertext classes. Hypertext Learning can increase the percentage of high student learning outcomes from $9 \%$ to $32 \%$.

Table 5

Analysis of Classroom NH and Hypertext Class Learning Results

\begin{tabular}{lrr}
\hline \multirow{2}{*}{ No. } & \multicolumn{2}{c}{$\%$ Gain } \\
\cline { 2 - 3 } & NH Class & Hypertext Class \\
\hline 1 & 20,0 & 40,0 \\
\hline 3 & 17,5 & 40,5 \\
\hline 4 & 15,0 & 68,0 \\
\hline 5 & 45,0 & 40,0 \\
\hline 6 & 55,0 & 47,5 \\
\hline 7 & 27,5 & 52,5 \\
\hline 8 & 15,0 & 55,0 \\
\hline 9 & 37,5 & 50,0 \\
\hline 10 & 45,0 & 58,0 \\
\hline 11 & 35,0 & 35,5 \\
\hline 12 & 35,0 & 53,0 \\
\hline 13 & 37,5 & 65,5 \\
\hline 14 & 60,0 & 55,0 \\
\hline 15 & 15,0 & 45,0 \\
\hline 16 & 2,5 & 52,5 \\
\hline 17 & 10,0 & 60,5 \\
\hline 18 & 37,5 & 60,5 \\
\hline 19 & 17,5 & 55,0 \\
\hline 20 & $-27,5$ & 50,0 \\
\hline 21 & 35,0 & 42,5 \\
\hline 22 & 10,0 & 37,5 \\
\hline 23 & 32,5 & 45,0 \\
\hline 24 & $-2,5$ & 32,5 \\
\hline 25 & 2,0 & 32,5 \\
\hline 26 & 2,0 & 27,5 \\
\hline 27 & 15,0 & 45,0 \\
\hline 28 & 35,0 & 32,5 \\
\hline & 35,0 & 40,0 \\
\hline
\end{tabular}




\begin{tabular}{lrr}
\hline \multirow{2}{*}{ No. } & \multicolumn{2}{c}{$\%$ Gain } \\
\cline { 2 - 3 } & NH Class & \multicolumn{2}{c}{ Hypertext Class } \\
\hline 29 & -5 & 37,5 \\
\hline 30 & 22,5 & 35,0 \\
\hline 31 & 7,5 & 37,5 \\
\hline 32 & 10,0 & 30,0 \\
\hline 33 & 5,0 & 32,5 \\
\hline 34 & 7,5 & 30,0 \\
\hline 35 & 10,0 & 32,5 \\
\hline Avarage & 11,0 & 44,0 \\
\hline
\end{tabular}

There is a significant difference in learning outcomes between $\mathrm{NH}$ classes and Hypertext classes. Hypertext Learning can increase the percentage of learning outcomes from $11 \%$ to $44 \%$.

\section{c. Achieved Outcomes}

From the results of research activities that have been implemented in Cibabat 5 Elementary School and Cibabat Mandiri 3 Cibahi Elementary School obtained some outcomes according to the plan that has been described in the previous chapter. The results are as follows:

Table 6

\section{Research Survey}

\begin{tabular}{cll}
\hline No. & \multicolumn{1}{c}{ Output Type } & \multicolumn{1}{c}{ Outcome Indicators } \\
\hline 1 & Scientific publications in journals & Accepted \\
\hline 2 & Publication on mass media (print / electronic) & Draft \\
\hline 3 & $\begin{array}{l}\text { Improved understanding and skills of the } \\
\text { community }\end{array}$ & Achieved \\
\hline 4 & $\begin{array}{l}\text { Services, models, social engineering, systems, } \\
\text { products / goods }\end{array}$ & Achieved \\
\hline
\end{tabular}

Outcomes that have been implemented as described above are activities to improve understanding and skills of society and services, models, social engineering, systems, products / goods through mentoring activities aimed at elementary school teachers in SDN Cibabat 5 and SDN Cibabat Mandiri 3 The next publication is the scientific publication in the journal / proceedings which will be published in September 2017 to the Journal of Primaryedu STKIP Siliwangi Bandung. In addition to the outcomes that have been delivered, there are several outpourings among them as follows:

1. The data of other research results can be used as material as data and facts for the material of final project completion (thesis) / research and can be published.

2. There is a follow-up program for the next year of program development based on program evaluation, whether conducted by the monev team or SD. 
3. Increased students and elementary school teachers who do Hypertext learning.

4. Socialization of collaborative research between lecturers and students of PGSD STKIP Siliwangi Bandung through $\mathrm{x}$-banner posters that can introduce this program more widely as a result of program implementation.

5. Increased understanding of learning at elementary level for students, as well as teachers.

\section{CONCLUSION}

Based on the results of research conducted in SDN Cibabat 5 and SDN Cibabat Mandiri 3 Kota Cimahi, it can be concluded things as follows:

1. Learning Hypertext can improve the cognitive aspects of elementary students on the subject of simple aircraft.

2. Improvement of Hiperteks classroom learning outcomes is greater than $\mathrm{NH}$ class (33\%) and there are significant differences in learning outcomes among each group of students.

\section{ACKNOWLEDGMENTS}

The Chief Researcher expressed his gratitude to the Mandiri Research Team, SDN Cibabat 5, and SDN Cibabat Mandiri 3 for the Grant Fund given and good cooperation. We will keep our trust and mother confidence and will continue to develop in future studies.

\section{REFERENCES}

Arıcı, N. \&Dalkılıç, E. (2006). The contribution of animations to computer assisted education: an application sample. Kastamonu Education Journal, 14 (2), $421-430$.

Aslan, Z. \& et al. (2011).Measurement of night sky brightness in Turkey. Proceedings Book of 8th National Lighting Congress, 14-15 April, pp. 69, ISBN: 978-975-561-392-5.

Bar, V., \&Galili, I. (1994). Stages of children's views about evaporation. International Journal of Science Education, 16(2), 157-174.

Berners-Lee. (1995). What is Hypertext. Tersedia: http://www.w3org/people/ Berners-Lee Board on Science Education \& National Research Council (U.S.) (2007).Taking science to school: Learning and teaching science in grades K-8. Washington, D.C.: National Academies Press.

Carrier, S. J. (2009).The effects of outdoor science lessons with elementary school students on preservice teachers' self-efficacy. Journal of Elementary Science Education, 21 (2), 35-48. DOI: 10.1007/BF03173683.

Cinzano, P., Falchi, F. \&Elvidge, C. D. (2001). The first world atlas of the artificial night sky brightness. Monthly Notices of the Royal Astronomical Soceity, 328, 689-707. http://www.lightpollution.it/cinzano/download/0108052.pdf

Crawford D. L. (2001). Light pollution channging the situation to everyone's advantage. Preserving TheAstronimical Sky, IUA Symposia, 196, 33-38.

Çepni, S. (2009). Effects of computer supported instructional material (CSIM) in removing, students' misconceptions about concepts: "light, light source and seeing". Energy 
Education Science and Technology, Part B: Social and Educational Studies, 1(2), 5183.

Çetegen, D. \& Batman, A. (2005). Light pollution. Journal of İstanbul Kültür University, 2, 29- 34.

DemircioğluYıldız, N. \&Yılmaz, H. (2005). Light pollution: problems and solution proposals. Journal of Atatürk University Faculty of Agriculture, 36(1), 117-123.

Duschl, R. A., Schweingruber, H. A., Shouse, A. W., National Research Council (U.S.). Committee on Science Learning Kindergarten Through Eighth Grade. National Research Council (U.S.).

Ersoy, A. F. \&Türkkan, B. (2010). Analyzing social and environmental issues elementary school students reflect in their cartoons. Education and Science, 35 (156), 96-109.

Flavell, J. H. ( 2000 ). Development of children's knowledge about the mental world. International Journal of Behavioral Development, 24, 15-23.

Gobert, J., \& Buckley, B. (2000). Special issue editorial: Introduction to model-based teaching and learning. International Journal of Science Education, 22(9), 891-894.

Goldberg, F., \&Bendall, S. (1995).Making the invisible visible: A teaching/learning environment that builds on a new view of the physics learner. American Journal of Physics 63(11), 978-991.

Hammond, N. (1993). Learning with Hypertext:Problems, Principles, and Prospects, Hypertext a psychology perspective editors C. McKnight, A. Dillon and J. Richardson. 51-66.

Hanel, A. (2001). The situation of light pollution in Germany. Preserving The Astronomical Sky, IUA Symposia, 196, 142-146.

Jose, T. J. \& Williamson, V. M. (2005). Molecular visualization in science education: An evaluation of the NSF funded workshop. Journal of Chemical Education, 82(6), 937943.

Keogh, B., Naylor, S. \& Wilson, C. (1998). Concept cartoons: a new perspective on physics education. Physics Education, 33(4), 219- 224. DOI:10.1088/0031-9120/33/4/009.

Keogh, B. \& Naylor, S. (1999). Concept cartoons, teaching and learning in science: an evaluation. International Journal of Science Education, 21(4), 431- 446. DOI:10.1080/095006999290642.

Klausmeier, H. J. (1992). Concept learning and concept teaching.Educational Psychologist, 27(3), 267.

Kurzon. (1995). Some Cohesion and Coherence Problem in Hypertext Discource. Tersedia: http//www.theorece, nus.eg/landow/CV/98Iboo.html

Larkin, J., \& Simon, H. (1987). Why a diagram is (sometimes) worth ten thousand words. Cognitive Science, 11, 65-99.

Mandler, J. M. (2008). On the birth and growth of concepts.Philosophical Psychology, 21(2), 207- 230.

Mayer, R.E., \& Anderson, B. (1991). Animations need narrations: An experimental test of a dualcodinghypothesis. Journal of Educational Psychology, 3, 484-490.

Mayer, R.E., \& Chandler, P. (2001). When learning is just a click away: Does simple user interaction foster deeper understanding of multimedia messages? Journal of Educational Psychology, 93, 390-397.

Mayer, R. E., Hegarty, M., Mayer, S., \& Campbell, J. (2005).When static media promote active learning: Annotated illustrations versus narrated animations in multimedia instruction. Journal of Experimental Psychology: Applied, 11(4), 256-265.

Mayer, R. E., \& Moreno, R. (2003).Nine ways to reduce cognitive load in multimedia learning. Educational Psychologist, 38, 43-52. 
McNamara, D. S., Kintsch, E., Songer, N. B., \&Kintsch, W. (1996). Are good texts always better?Interactions of text coherence, background knowledge, and levels of understanding in learning from text. Cognition and Instruction, 14(1), 1-43.

Metcalfe, J., \&Shimamura, A. P. (1994). Metacognition: knowing about knowing. Cambridge, MA: MIT Press. National Research Council (U.S.) (1996). National science education standards: Observe, interact, change, learn. Washington, DC: National Academy Press.

Miall, D.S. (1997). Reading and Writing Hypertext. Tersedia http://www.ualberta.ca./dmiall/miall.html

Osman A., Isobe S. Nawar \&Morcos A. B. (2001). Light pollution and energy loss from Cairo. Preserving The Astronomical Sky, IUA Symposia, 196, 107-110.

Özyılmaz-Akamca, G. \&Hamurcu, H. (2009).Science and technology education based on analogies, concept cartoons and predict-observe-explain techniques. E-Journal of New World Sciences Academy, 4(4), 1186-1206.

Percy, J. R. (2001). Light pollution: education of students, teachers, and the public. Preserving The Astronomical Sky, IUA Symposia, 196, 353-358.

Priest, S. (1986). Redefining outdoor education: a matter of many relationships. The Journal of Envirionmental Education. 17 (3), 13-15. DOI: 10.1080/00958964.1986.9941413.

Project 2061 (American Association for the Advancement of Science) (1993).Benchmarks for science literacy. New York: Oxford University Press.

Rieber, L. P. (1990). Using computer animated graphics in science instruction with children. Journal of Educational Psychology, 82, 135-140.

Rotbain, Y., Romance, N. R., \& Vitale, M. R. (2001).Implementing an in-depth expanded science model in elementary schools: Multi-year findings, research issues, and policy implications. International Journal of Science Education, 23, 373-404.

Romance, N. R., \& Vitale, M. R. (2010).Effects of an integrated instructional model for accelerating student achievement in science and reading comprehension in grades 12.Presented at the Annual Meeting of the American Educational Research Association, Denver, CO.

Marbach-Ad, G. \&Stavy, R. (2008). Using a computer animation to teach high school molecularbiology. Journal of Science Education and Technology, 17, 49-58. DOI: 10.1007/s10956-007-9080-4.

Sadık, F., Çakan, H. \&Artut, K. (2011). Analysis of the environmental problems pictures of children from different socio-economical level. Elementary Education Online, 10661080 .

Seçgin, F., Yalvaç, G. \&Çetin, T. (2010). Environmental problem perceptions of 8th grade students through cartoons. Proceedings Book of International Conference on New Trends in Education and Their Implications (iconte), 11-13 November, ISBN: 978 6053641049 , pp. 391-398.

Schneider, W. (2008). The development of metacognitive knowledge in children and adolescents: Major trends and implications for education. Mind, Brain, and Education, 2, 114- 121.

Shwartz, Y., Weizman, A., Fortus, D., Krajcik, J., \&Reiser, B. (2008). Middle school science curriculum: Coherence as a design principle. Paper presented at the National Association of Research in Science Teaching.

Slotta, J. D., \& Chi, M. T. H. (2006). The impact of ontology training on conceptual change: Helping students understand the challenging topics in science.

Siregar, N. (2002). Potensi Hiperteks sebagai Inti Pengembangan Skripsi untuk Menanggulangi Kesulitan Pengajaran dan Pembelajaran (Tidak diterbitkan). Bandung: FPMIPA UPI. 
Taşlidere, E. (2013). The effect of concept cartoon worksheets on students' conceptual understandings of geometrical optics. Education and Science, 38 (167), 144-161.

Witarsa, R. (2005). Penggunaan Hiperteks untuk Meningkatkan Pemahaman Aspek Kognitif Siswa pada Pokok Bahasan Hidrokarbon. Skripsi. Bandung: Tidak Diterbitkan. 